\title{
Real Time Ambient Air Quality Status during Diwali Festival in Central, India
}

\author{
Shivangi Nigam*, Navneet Kumar, N. K. Mandal, B. Padma, S. Rao \\ National Environmental Engineering Research Institute (NEERI), Council of Scientific and Industrial Research \\ (CSIR), Nagpur, Maharashtra \\ Email: *s_nigam@neeri.res.in
}

Received 9 July 2015; accepted 26 January 2016; published 29 January 2016

Copyright (C) 2016 by authors and Scientific Research Publishing Inc.

This work is licensed under the Creative Commons Attribution International License (CC BY). http://creativecommons.org/licenses/by/4.0/

c) (5) Open Access

\begin{abstract}
In India, festivals are celebrated with lot of enthusiasm and Diwali is the major festival of light. In this festival, houses are illuminated by lights and sky is illuminated by fireworks. These fireworks though create lot of amusement but also pollute the atmosphere in terms of air pollution. The continuous air pollution monitoring was undertaken during Diwali festival (2014) at residential site NEERI, Nagpur. Air quality parameters were compared with CPCB standard. On Diwali day, PM10 and $P M_{2.5}$ concentration achieve its highest value of $900 \mu \mathrm{g} / \mathrm{m}^{3}$ and $950 \mathrm{respectively} \mu \mathrm{g} / \mathrm{m}^{3}$. This high concentration is maintained in atmosphere for two days of this festival in atmosphere which is approximately 8 - 9 times more than that regulatory standard. These particles carry all the components of the cracker including heavy metals, alkali metals, alkaline earth and change the atmosphere with positive and negative ions apart from impaction of sulfur and other acid gases to the atmosphere.
\end{abstract}

\section{Keywords}

$\mathrm{PM}_{10}, \mathrm{PM}_{2.5}$, Diwali, Fireworks, Correlation, Regression, Nagpur

\section{Introduction}

Diwali festival is celebrated in winter season around October, November every year. Due to atmospheric inversion \& cold climate, the air pollution load is very high as the pollution load is very high and the pollutants tend to settle down due to low dispersion \& dilution in the atmosphere. The urban air quality of India is hereby experiencing increased $\mathrm{PM}_{10}$ concentration. During Diwali festival time, it attains episodic high level in the air quality. The central India which explains land experiences extreme climate during the festival onset of winter is tak-

"Corresponding author.

How to cite this paper: Nigam, S., Kumar, N., Mandal, N.K., Padma, B. and Rao, S. (2016) Real Time Ambient Air Quality Status during Diwali Festival in Central, India. Journal of Geoscience and Environment Protection, 4, 162-172.

http://dx.doi.org/10.4236/gep.2016.41017 
en place which ties to settle the air pollutants thus giving lot of exposure to the pollution.

Nagpur is centrally located city in India where industrial and commercial growth is moderate. The city has a population of 46.53570 lakhs (2011 census). It is a big centre for industry, education and agriculture in Vidarbha region of Maharastra State. The city celebrates Diwali festival in which various types of crackers are burst, which generates lot of air pollution in atmosphere. This may cause episodic rise in $\mathrm{PM}_{10}$ and $\mathrm{PM}_{2.5}$ in atmosphere and imparts adverse effect on regional visibility, global climate change and health [1].

Daily Standard for $\mathrm{PM}_{10}$ and $\mathrm{PM}_{2.5}$ is $100 \mu \mathrm{g} / \mathrm{m}^{3}$ and $60 \mu \mathrm{g} / \mathrm{m}^{3}$ respectively [2]. In urban areas, the air quality largely varies on localities. The air quality of the city mainly depends upon activity going on the city like industrial activity, construction activity, transport activity etc.

In the present study, we intend to observe the immediate and short term effect of various activities like bursting of fireworks performed during the festival season on the ambient air. The CAAMS (Continuous Ambient Air Quality Monitoring System) was installed in the residential area and real time monitor 13th October to 28th October 2014 at NEERI Nehru Marg residential site (Environment S.A.).

\section{Materials and Methods}

\subsection{Study Area}

Nagpur $\left(21^{\circ} 15^{\prime} \mathrm{N}, 79^{\circ} 08^{\prime} \mathrm{E}\right)$ is the Capital of Maharashtra in the winter season. The district stretches to almost 9897 sq km. Nagpur is surrounded by plateau rising northward to the Satpura Range, Kanhan and Pench rivers are the two important rivers of the district. It is situated $274.5 \mathrm{~m}$ to $652.7 \mathrm{~m}$ above sea level and $28 \%$ of the town is covered by forest. The city has a typical seasonal monsoon weather which is normally dry. Average relative humidity (RH) is $60 \%$. Annual average temperature ranges from $33.2^{\circ} \mathrm{C}$ to $17.1^{\circ} \mathrm{C}$ with average annual rain fall $112 \mathrm{~mm}$. The average meteorological parameters during Diwali October 2014 have been monitored by Metrological Department Nagpur (Table 1).

\subsection{Methodology}

To see the impact of bursting of fireworks during Diwali festival on air quality the real time air quality monitoring was carried out at residential site NEERI, Nagpur (Figure 1) [3]. In the present study ambient air quality was

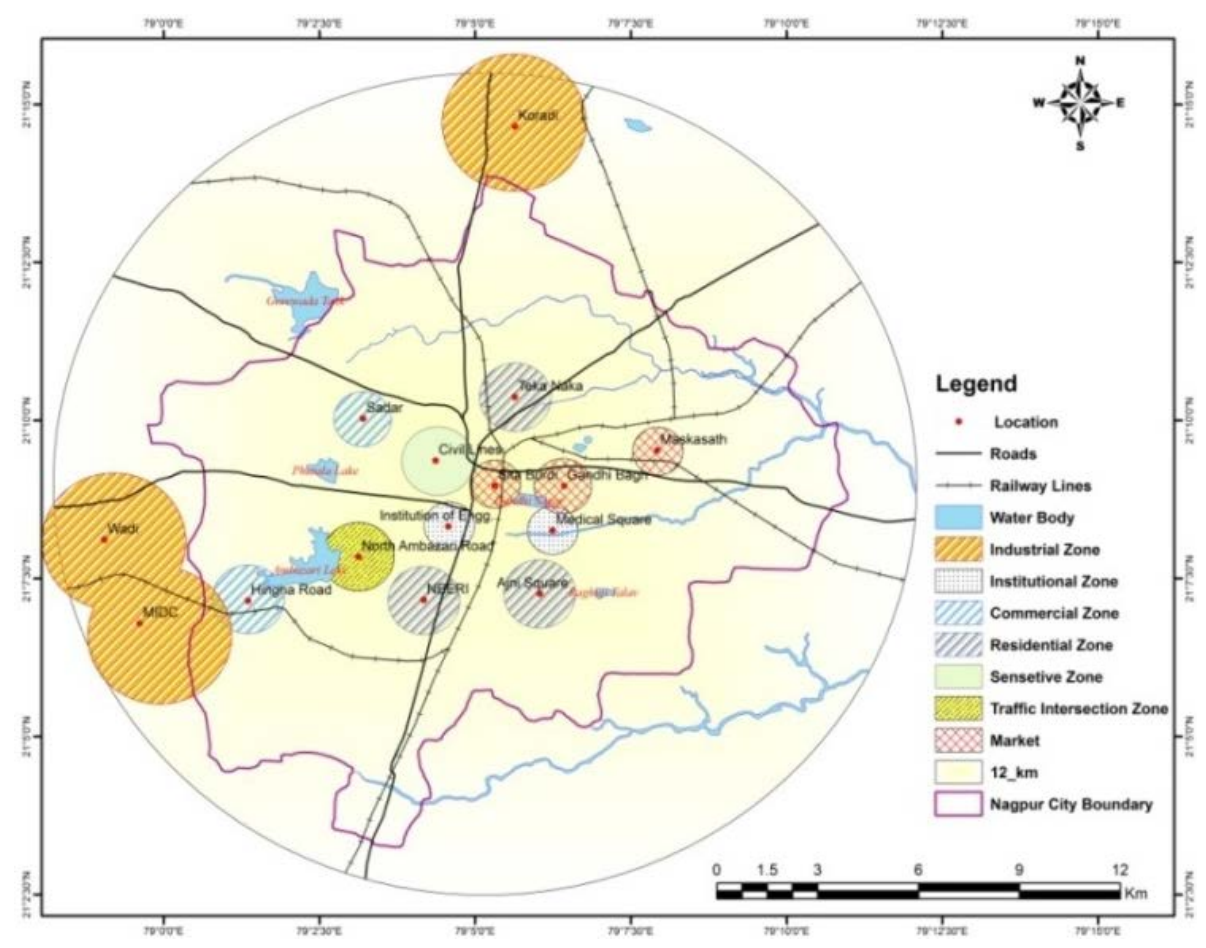

Figure 1. Study area NEERI, Nagpur residential site. 
Table 1. Climate data during month of October Diwali.

\begin{tabular}{|c|c|c|c|c|c|}
\hline Date & Temperature $\left({ }^{\circ} \mathrm{C}\right)$ & Wind $(\mathrm{m} / \mathrm{hr})$ & Wind Direction (deg) & Humidity (\%) & Pressure (mbar) \\
\hline $13 / 10 / 2014$ & 27.13 & 4.25 & $34^{\circ}(\mathrm{NE})$ & 35 & 1012.25 \\
\hline $14 / 10 / 2014$ & 28.5 & 4.5 & $84^{\circ}(\mathrm{E})$ & 70 & 1013 \\
\hline $15 / 10 / 2014$ & 28.63 & 4 & $96^{\circ}(\mathrm{E})$ & 49.13 & 1012.88 \\
\hline $16 / 10 / 2014$ & 28.5 & 3.88 & $203^{\circ}(\mathrm{SSW})$ & 72 & 1008 \\
\hline $17 / 10 / 2014$ & 27.63 & 5.38 & $68^{\circ}$ (ENE) & 52 & 1013.38 \\
\hline $18 / 10 / 2014$ & 28.13 & 3.25 & $98^{\circ}(\mathrm{E})$ & 52 & 1012.75 \\
\hline $19 / 10 / 2014$ & 28.5 & 2.38 & $119^{\circ}$ (ESE) & 53.63 & 1011.75 \\
\hline 20/10/2014 & 28.88 & 2.13 & $125^{\circ}(\mathrm{SE})$ & 52.75 & 1012.25 \\
\hline $21 / 10 / 2014$ & 28.88 & 4 & $82^{\circ}(\mathrm{E})$ & 54.63 & 1014 \\
\hline $22 / 10 / 2014$ & 27.63 & 4.25 & $71^{\circ}$ (ENE) & 44.50 & 1014.75 \\
\hline $23 / 10 / 2014$ & 27.38 & 2.38 & $77^{\circ}$ (ENE) & 44.13 & 1013.63 \\
\hline $24 / 10 / 2014$ & 27.38 & 2.5 & $130^{\circ}(\mathrm{SE})$ & 41.38 & 1012 \\
\hline $25 / 10 / 2014$ & 24.13 & 2.88 & $144^{\circ}(\mathrm{SE})$ & 66 & 1014.13 \\
\hline $26 / 10 / 2014$ & 21.63 & 1.75 & $157^{\circ}(\mathrm{SSE})$ & 80.14 & 1015.88 \\
\hline 27/10/2014 & 24.75 & 1.88 & $241^{\circ}$ (WSW) & 63.88 & 1015 \\
\hline
\end{tabular}

measured by CAAMS for fine particulate matter $\mathrm{PM}_{10} \& \mathrm{PM}_{2.5}$. The fine particulate monitor of CAAMS works on principle of Beta Attenuation Method for measuring and analysis of the concentration of $\mathrm{PM}_{10} \& \mathrm{PM}_{2.5}$. Every hour, a small $\mathrm{C}_{14}$ (Carbon -14 or Krypton 85) element emits a constant source of high-energy electrons (known as beta rays) through a spot of clean filter tape.

\section{Result \& Discussion}

The study of air quality in residential site Nagpur during pre Diwali, Diwali, post Diwali periods was aimed at comparing the air quality during these periods and to find out whether the air quality $\left(\mathrm{PM}_{10} \& \mathrm{PM}_{2.5}\right)$ is within the recommended standard. Diwali is the one of the greatest festival in India that attracts many from far and near thereby increasing human activities like fireworks. NEERI, Residential site was selected for measurement of continuous air quality. The avg. concentration of $\mathrm{PM}_{10}$ and $\mathrm{PM}_{2.5}$ has been given in Table 2 .

The diurnal variation and the concentration built up in linked to population exposure. The AQI (Air Quality Index) index reaches to dangerous limits indicating heavy impact on respiratory organs of exposed population. The hospital admission also projects alarming rise regarding respiratory disorders.

It is observed that $\mathrm{PM}_{10} \& \mathrm{PM}_{2.5}$ in the early morning hours (4 AM - $7 \mathrm{AM}$ ) and night hours (9 PM - $12 \mathrm{AM}$ ) was highest during the festival time (Figures 2-5). During this time most of the exposed populations are sleeping $\&$ hence a large impact on their respiration envisages. These values are approximating 8 - 9 times more than the CPCB standards of $\mathrm{PM}_{10} \& \mathrm{PM}_{2.5}$ values during festival period [4]-[9].

The value ranges between $100-900 \mu \mathrm{g} / \mathrm{m}^{3}$ for both $\mathrm{PM}_{10} \& \mathrm{PM}_{2.5}$ (Figures 6-9). This can be attributed by increase in anthropogenic activity such as bursting of Fireworks, transportation, other ritual activities etc. During $7 \mathrm{AM}$ - 9 PM the value of $\mathrm{PM}_{10} \& \mathrm{PM}_{2.5}$ is relatively less but high as compared to regulatory Standard. The value ranges between $80-200 \mu \mathrm{g} / \mathrm{m}^{3}$ for both $\mathrm{PM}_{10} \& \mathrm{PM}_{2.5}$. The episodic increase in the concentration level of fine particulates $\mathrm{PM}_{10} \& \mathrm{PM}_{2.5}$ reaches the threshold limits for set as $1000 \mu \mathrm{g} / \mathrm{m}^{3}$ by USEPA which is lately reduced lately [10]. 
Though the festive period is the time of lot of capital generation for businessmen by selling crackers and sweets, but providing healthy air common people is big question during festival time. In India the air quality standard for $\mathrm{PM}_{10}$ and $\mathrm{PM}_{2.5}$ are specified as $100 \mu \mathrm{g} / \mathrm{m}^{3}$ and $60 \mu \mathrm{g} / \mathrm{m}^{3}$ respectively [4]. It has been observed that extreme air quality has adverse effects on citizens [11]-[13].

Table 2. Avg. ambient concentration of $\mathrm{PM}_{10}, \mathrm{PM}_{2.5}$ during Diwali seasons.

\begin{tabular}{|c|c|c|c|c|c|c|}
\hline \multirow{2}{*}{ Time } & \multicolumn{2}{|c|}{ Pre Diwali } & \multicolumn{2}{|c|}{ During Diwali } & \multicolumn{2}{|c|}{ Post Diwali } \\
\hline & $\begin{array}{c}\mathrm{PM}_{10} \\
\left(\mu \mathrm{g} / \mathrm{m}^{3}\right)\end{array}$ & $\begin{array}{c}\mathrm{PM}_{2.5} \\
\left(\mu \mathrm{g} / \mathrm{m}^{3}\right)\end{array}$ & $\begin{array}{c}\mathrm{PM}_{10} \\
\left(\mu \mathrm{g} / \mathrm{m}^{3}\right)\end{array}$ & $\begin{array}{c}\mathrm{PM}_{2.5} \\
\left(\mu \mathrm{g} / \mathrm{m}^{3}\right)\end{array}$ & $\begin{array}{c}\mathrm{PM}_{10} \\
\left(\mu \mathrm{g} / \mathrm{m}^{3}\right)\end{array}$ & $\begin{array}{c}\mathrm{PM}_{2.5} \\
\left(\mu \mathrm{g} / \mathrm{m}^{3}\right)\end{array}$ \\
\hline $12 \mathrm{AM}$ & 117.85 & 64.485 & 100.79 & 342.99 & 118.65 & 85.81 \\
\hline $1 \mathrm{AM}$ & 106.31 & 60.585 & 107.04 & 75.98 & 115.59 & 87.52 \\
\hline $2 \mathrm{AM}$ & 104.59 & 62.52 & 98.98 & 67.53 & 104.72 & 73.92 \\
\hline ЗАM & 105.16 & 55.22 & 91.29 & 58.52 & 93.95 & 63.05 \\
\hline $4 \mathrm{AM}$ & 100.30 & 61.28 & 383.81 & 366.44 & 83.60 & 55.75 \\
\hline $5 \mathrm{AM}$ & 104.32 & 65.38 & 340.82 & 330.86 & 74.31 & 49.90 \\
\hline $6 \mathrm{AM}$ & 94.69 & 56.64 & 217.13 & 195.50 & 65.52 & 47.97 \\
\hline $7 \mathrm{AM}$ & 89.44 & 57.41 & 138.35 & 124.09 & 59.41 & 42.73 \\
\hline $8 \mathrm{AM}$ & 92.69 & 57.15 & 110.88 & 79.928 & 55.52 & 34.09 \\
\hline $9 \mathrm{AM}$ & 112.85 & 53.85 & 105.30 & 64.52 & 63.69 & 42.55 \\
\hline $10 \mathrm{AM}$ & 107.37 & 63.38 & 105.79 & 69.43 & 61.82 & 42.72 \\
\hline $11 \mathrm{AM}$ & 102.55 & 53.89 & 119.32 & 70.24 & 62.77 & 43.23 \\
\hline $12 \mathrm{PM}$ & 90.29 & 54.33 & 125.21 & 73.18 & 56.41 & 41.17 \\
\hline $1 \mathrm{PM}$ & 75.90 & 40.86 & 108.07 & 61.72 & 49.93 & 29.12 \\
\hline $2 \mathrm{PM}$ & 74.55 & 36.85 & 89.69 & 53.03 & 56.80 & 24.62 \\
\hline 3РM & 68.91 & 30.48 & 82.83 & 45 & 69.72 & 33.62 \\
\hline $4 \mathrm{PM}$ & 62.52 & 37.47 & 79.27 & 46.07 & 70.54 & 38.20 \\
\hline $5 \mathrm{PM}$ & 69.52 & 44.81 & 80.23 & 33.74 & 75.81 & 35.9 \\
\hline $6 \mathrm{PM}$ & 70.28 & 40.41 & 72.30 & 41.16 & 82.57 & 49.76 \\
\hline $7 \mathrm{PM}$ & 68.44 & 42.21 & 74.40 & 49.15 & 92.14 & 49.08 \\
\hline 8PM & 85.74 & 48.32 & 88.20 & 53.34 & 94.53 & 58.63 \\
\hline 9PM & 109.08 & 55.94 & 107.23 & 68.19 & 103.33 & 59.47 \\
\hline $10 \mathrm{PM}$ & 103.33 & 63.43 & 170.38 & 125.09 & 106.15 & 72.99 \\
\hline $11 \mathrm{PM}$ & 97.09 & 57.31 & 311.43 & 245.29 & 110.12 & 78.08 \\
\hline Avg. Conc. & 92.24 & 52.68 & 137.868 & 114.21 & 80.32 & 51.66 \\
\hline AQI & 0.92 & 0.88 & 1.38 & 1.90 & 0.80 & 0.86 \\
\hline
\end{tabular}




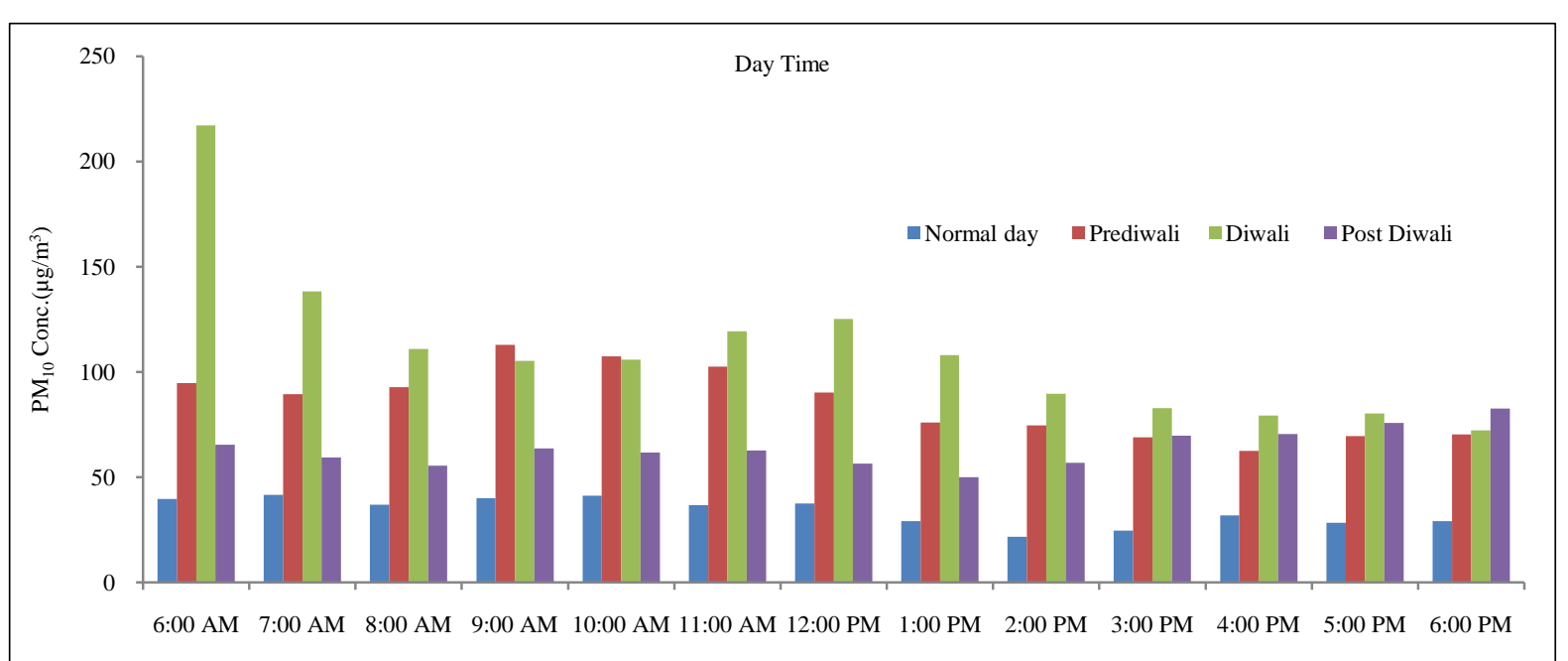

Figure 2. Variation of concentration of $\mathrm{PM}_{10}$ in day time during Diwali days.

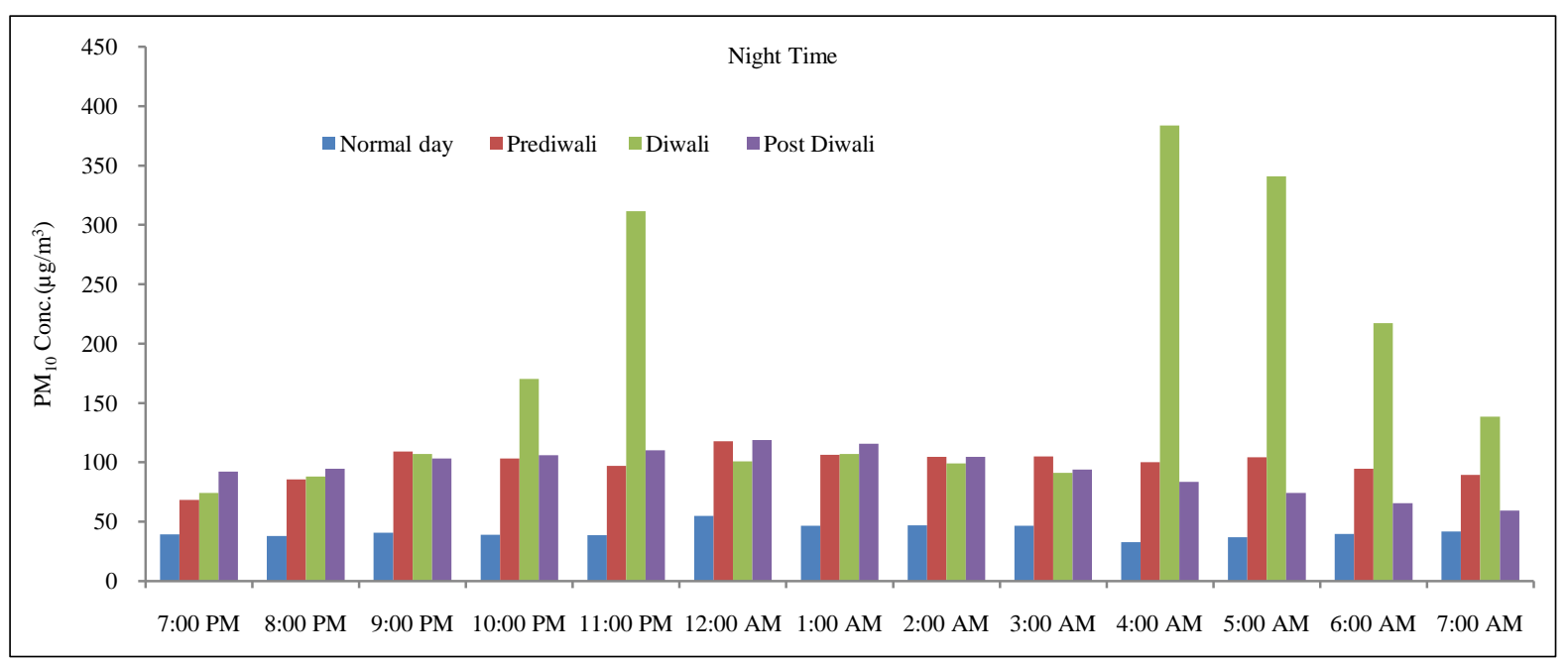

Figure 3. Variation of concentration of $\mathrm{PM}_{10}$ in night time during Diwali days.

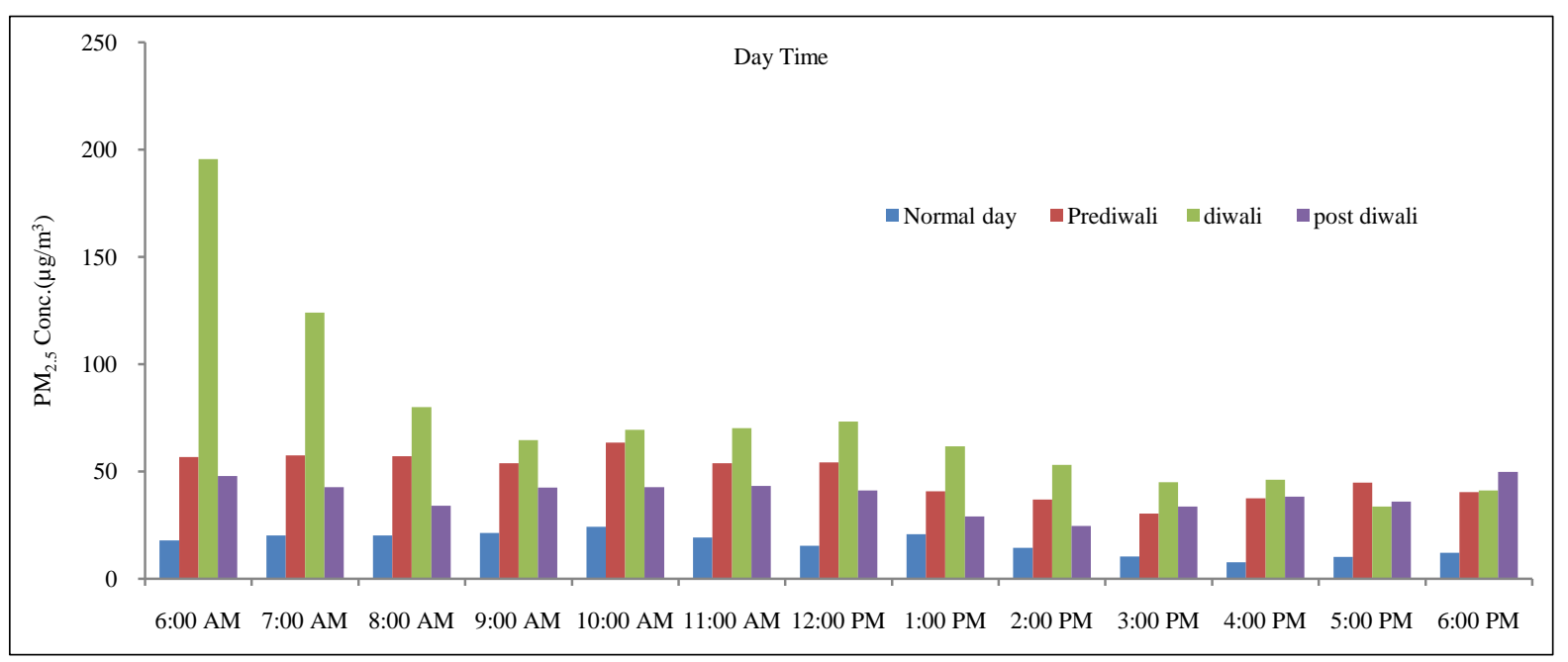

Figure 4. Variation of concentration of $\mathrm{PM}_{10}$ in day time during Diwali days. 


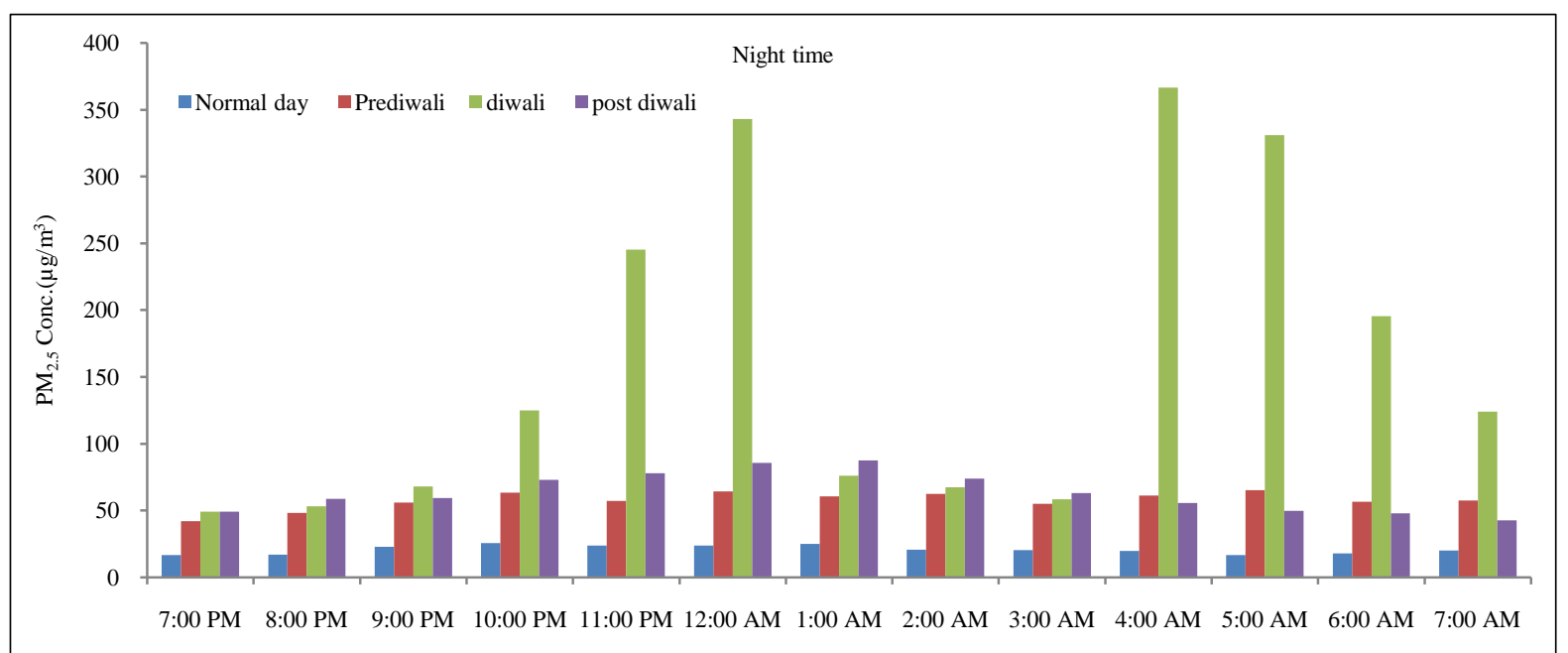

Figure 5. Variation of concentration of $\mathrm{PM}_{2.5}$ in day time during Diwali days.

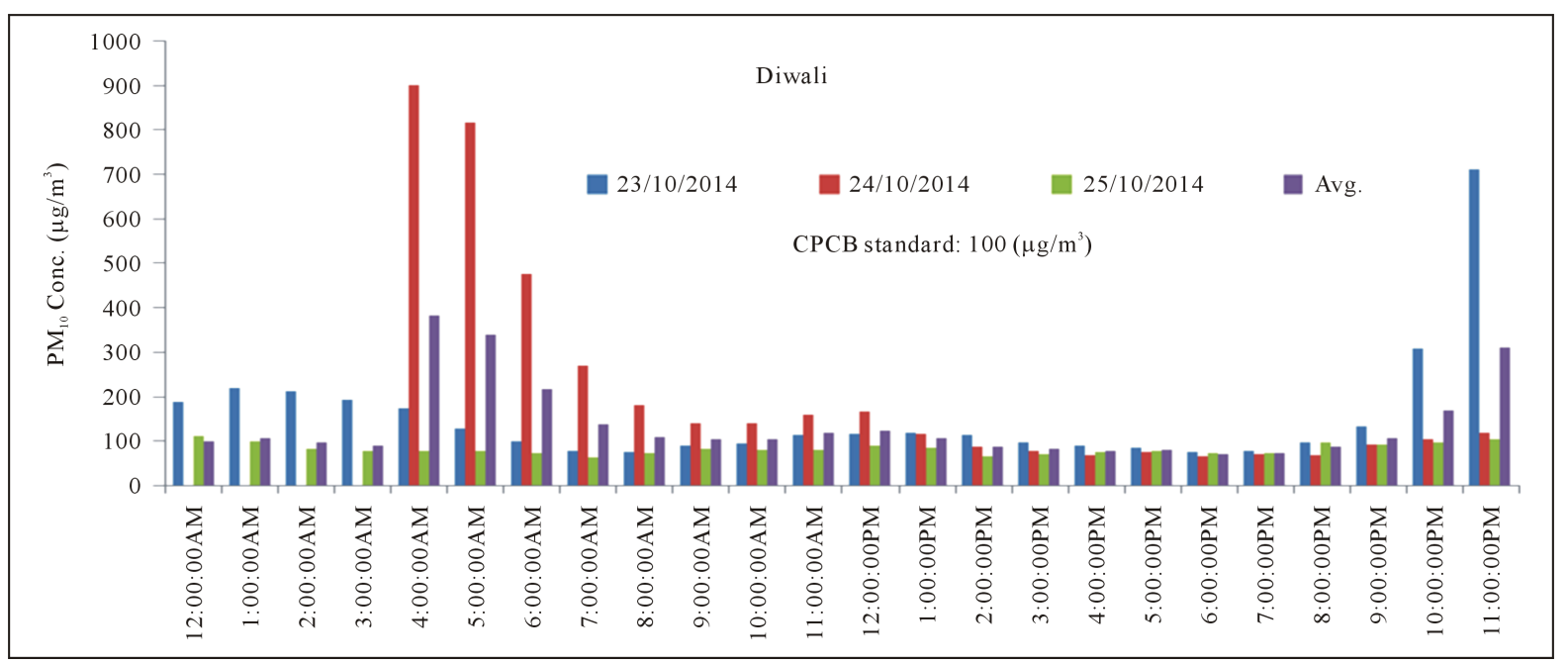

Figure 6. Diurnal variation of $\mathrm{PM}_{10}$ during Diwali days.

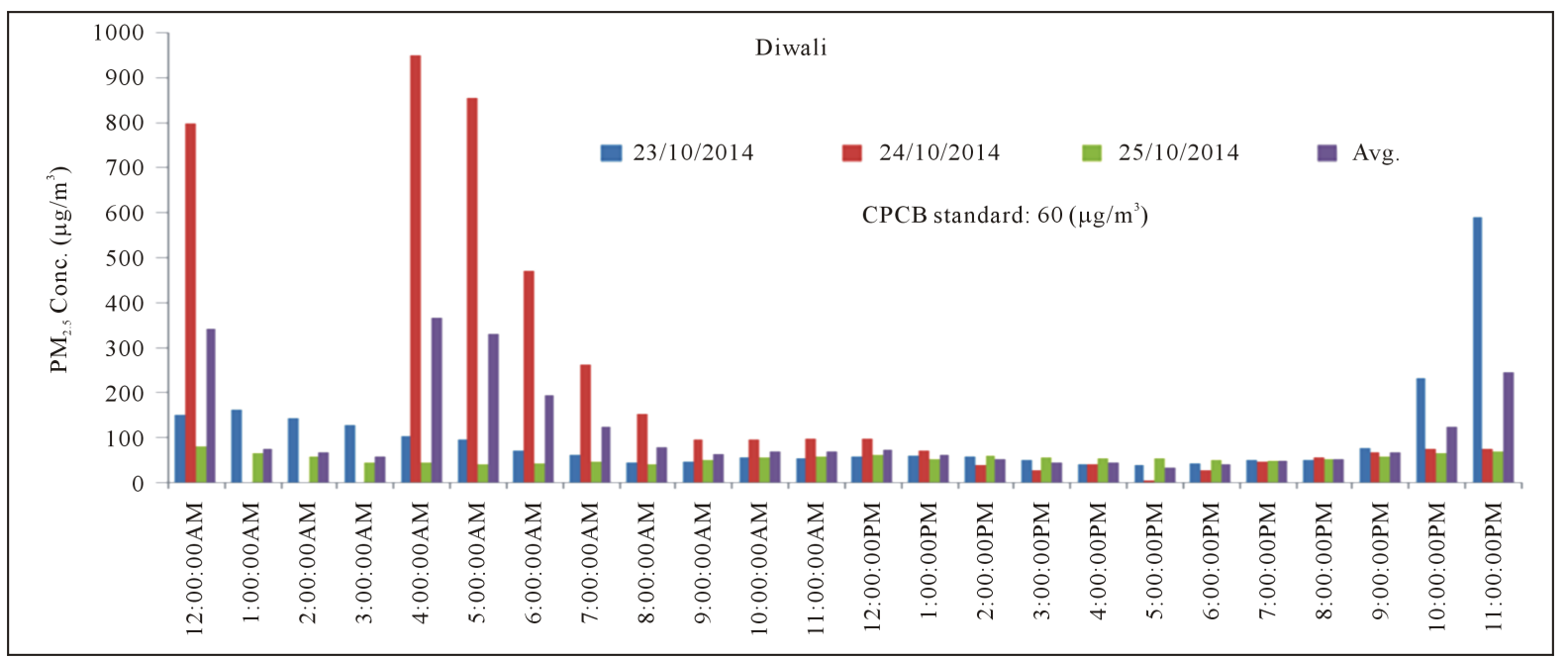

Figure 7. Diurnal variation of $\mathrm{PM}_{2.5}$ during Diwali days. 


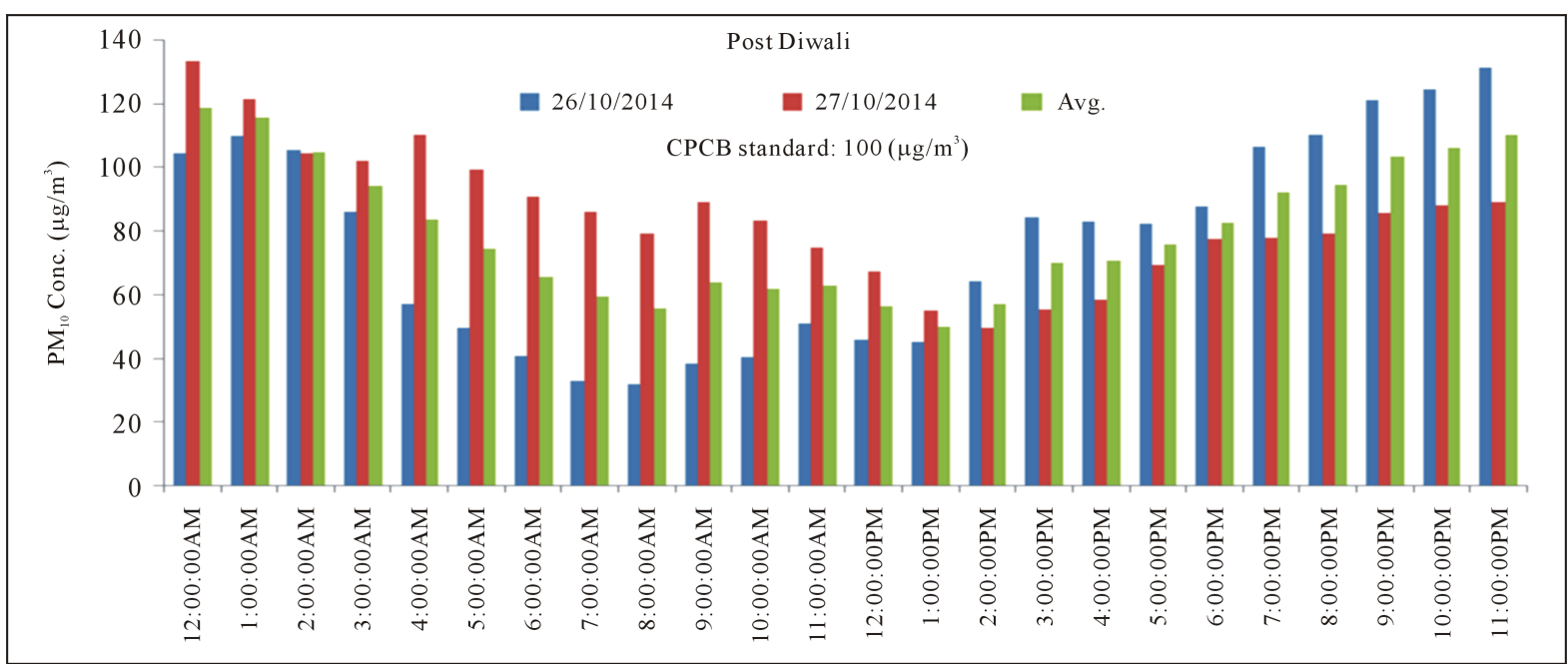

Figure 8. Diurnal variation of $\mathrm{PM}_{10}$ after Diwali.

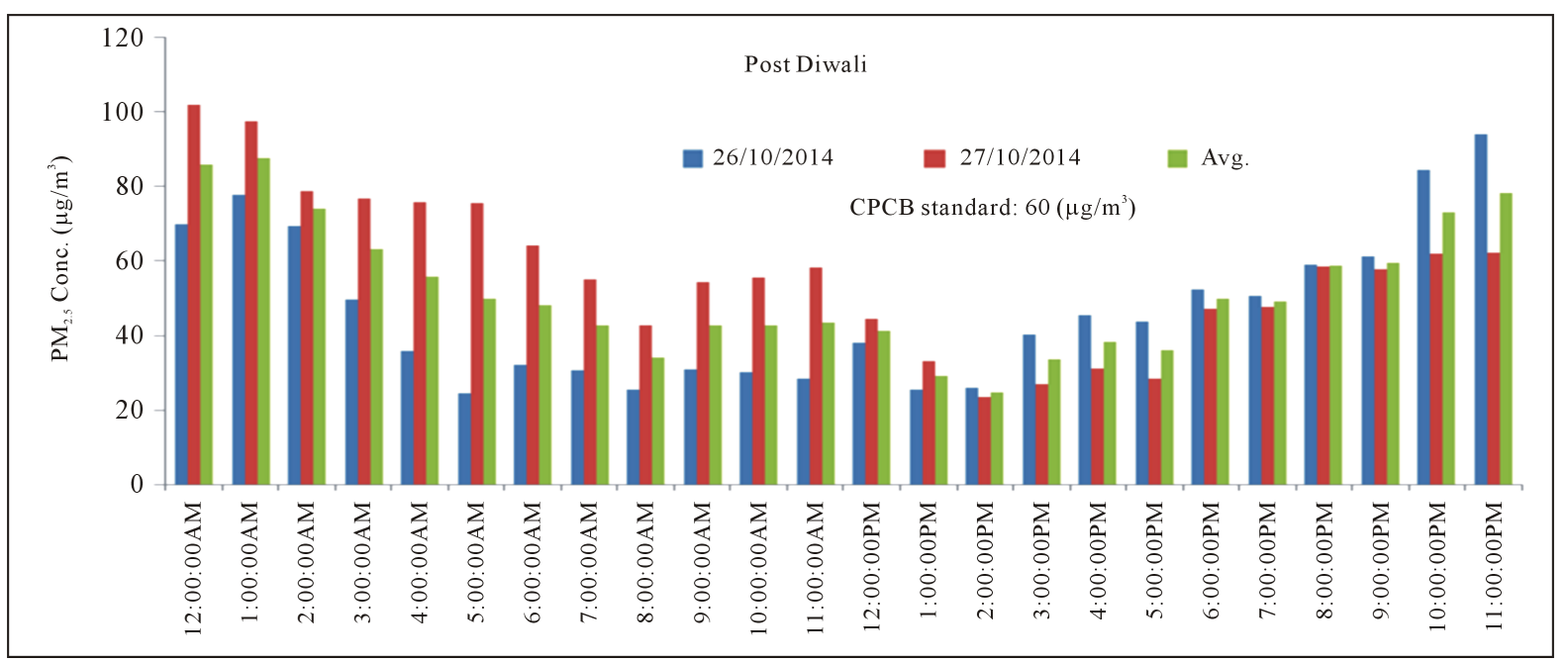

Figure 9. Diurnal variation of $\mathrm{PM}_{2.5}$ during Diwali days.

The increase concentration of particulate matter $\left(\mathrm{PM}_{10} \& \mathrm{PM}_{2.5}\right)$ leads to increase in the cations concentration in atmosphere which causes serious health hazard [14]. Heavy metal characterization is shown in Figure 10 and Figure 11 for $\mathrm{PM}_{10}$ and $\mathrm{PM}_{2.5}$ respectively. It has been scientifically proven that particulate matter $\left(\mathrm{PM}_{10} \&\right.$ $\mathrm{PM}_{2.5}$ ) more than standard value can cause acute respiratory effect [15] [16]. The quality of life of people is well being described by individual's health [17]. Health includes physical, psychological and social well being of an individual [18]. The statistical tool SPSS is used to analyze the data; correlation coefficient and regression coefficient were performed between pollutants $\mathrm{PM}_{10}$ and $\mathrm{PM}_{2.5}$. The summary of ambient air pollutant is presented in Table 3, Table 4, and Table 5. It has found that ambient air quality in terms of $\mathrm{PM}_{10}$ and $\mathrm{PM}_{2.5}$ has drastic change as compared to normal (correlation coefficient $=0.6$ ). Even in the post Diwali the condition of air quality is bad. It is negatively correlated with the normal in day time where as the condition is far better in night time during post Diwali days.

It was observed that linear regression of $\mathrm{PM}_{10}$ and $\mathrm{PM}_{2.5}$ has strong relationship during day time $\left(\mathrm{R}^{2}>0.9\right)$. In the night time $\mathrm{PM}_{10} \& \mathrm{PM}_{2.5}$ has moderate relationship $\left(\mathrm{R}^{2}>0.5\right)$.

Diwali festival is generally celebrated in month of October-November. The meteorology of these seasons is falls in calm condition which may have substantial impact on ambient concentration and ambient air quality greatly varies according the local activity such as transport and small scale industry. The dispersion of concentration these pollutants $\mathrm{PM}_{10} \& \mathrm{PM}_{2.5}$ is depicted in Figure 12 and Figure 13. The dispersion contours has been 


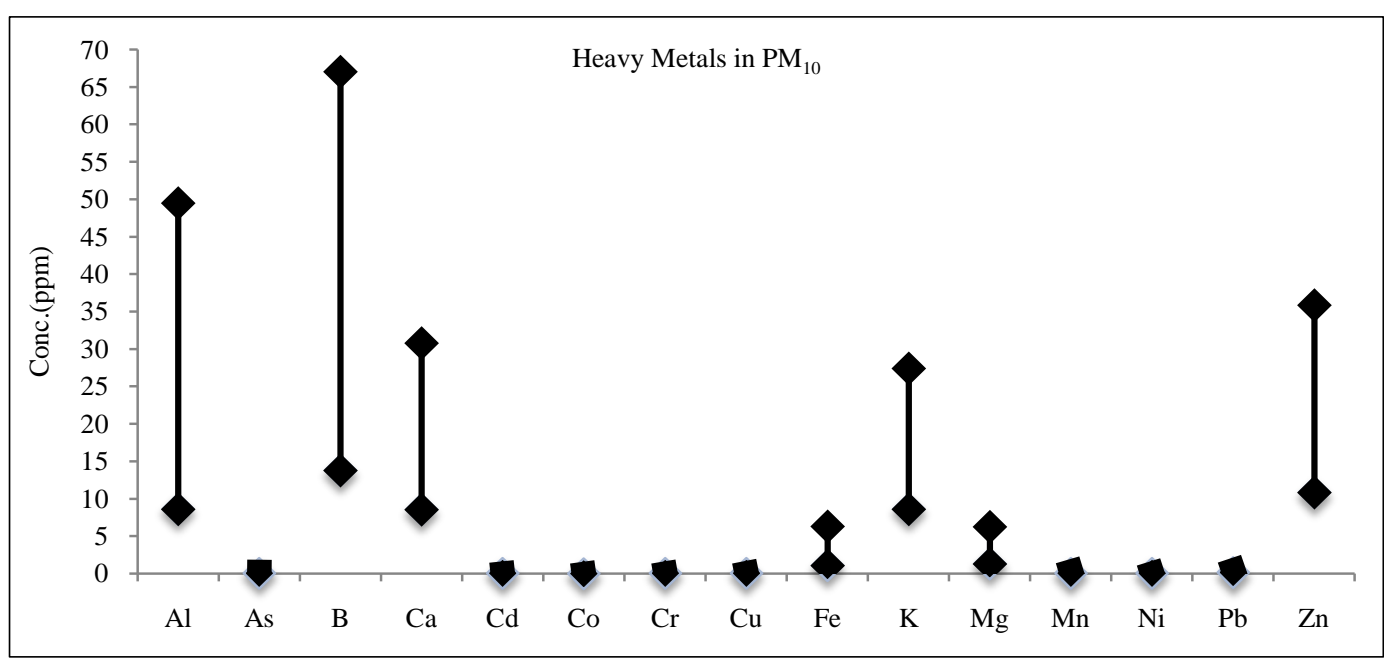

Figure 10. Heavy metal characterizations in $\mathrm{PM}_{10}$ during Diwali festival.

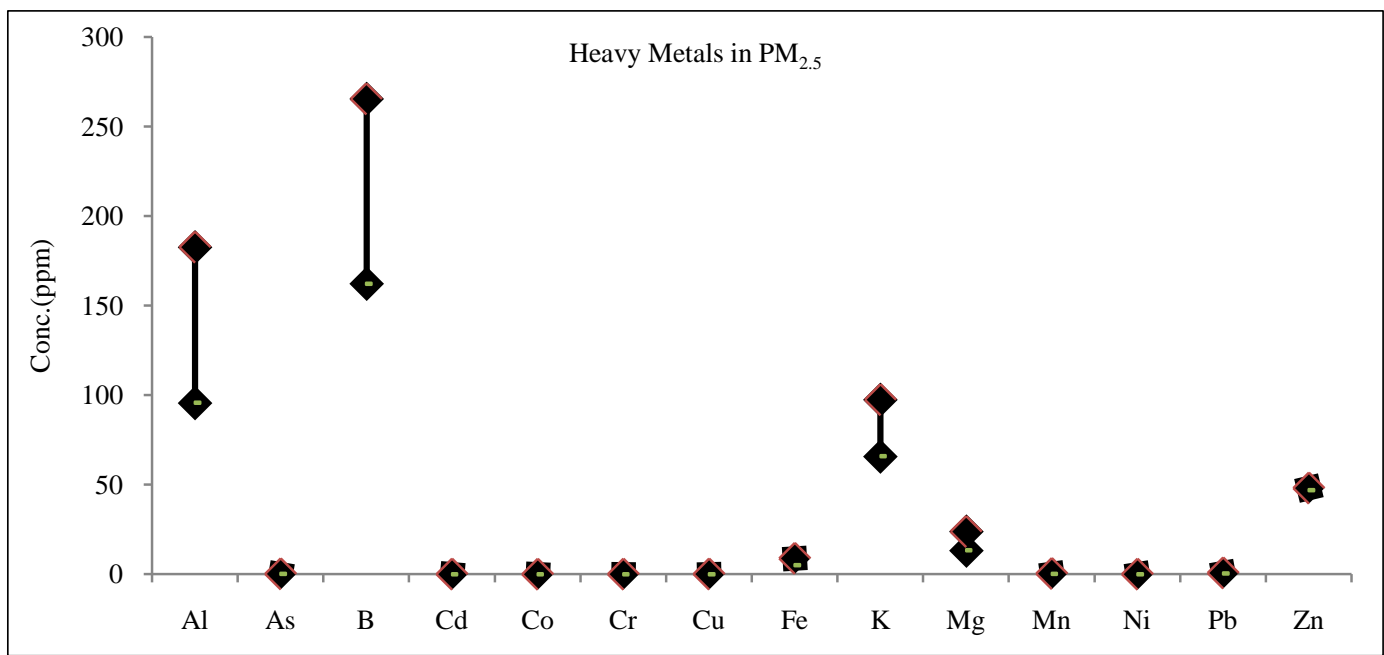

Figure 11. Heavy metal characterizations in $\mathrm{PM}_{2.5}$ during Diwali festival.

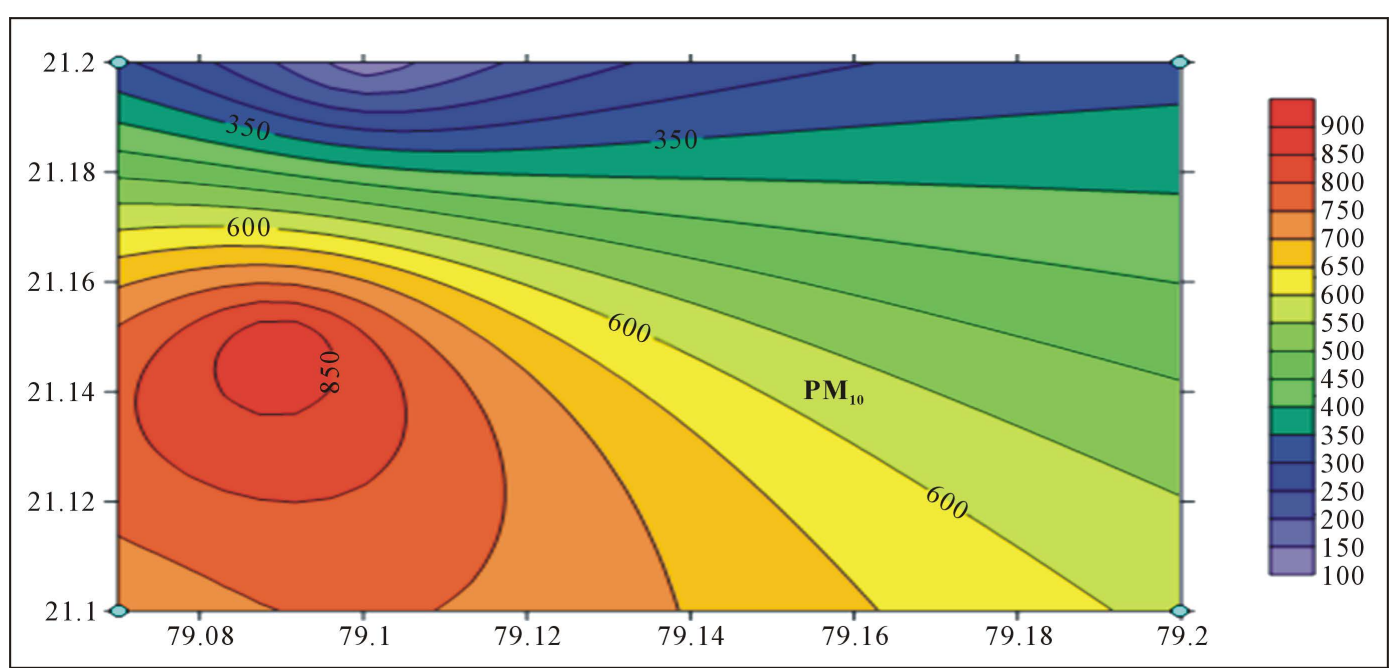

Figure 12. Dispersion of $\mathrm{PM}_{10}$ across the Nagpur city during Diwali days. 


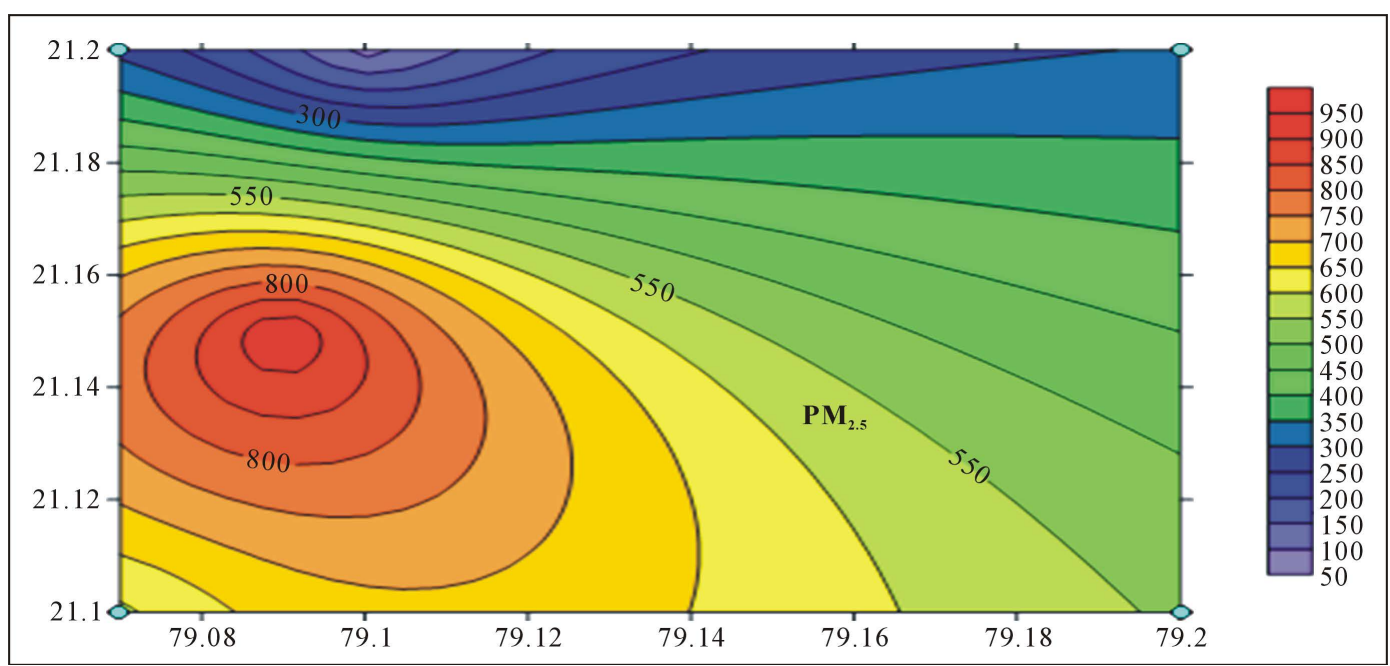

Figure 13. Dispersion of $\mathrm{PM}_{2.5}$ across the Nagpur city during Diwali days.

Table 3. Summary of air quality during day times of Diwali days.

\begin{tabular}{|c|c|c|c|c|}
\hline \multicolumn{5}{|c|}{ Correlation Coefficient of Pollutant During Day Time } \\
\hline $\mathrm{PM}_{10}$ & Normal Day & Pre Diwali & Diwali & Post Diwali \\
\hline Normal Day & 1 & & & \\
\hline Pre Diwali & 0.80 & 1 & & \\
\hline Diwali & 0.60 & 0.48 & 1 & \\
\hline Post Diwali & -0.23 & -0.39 & -0.33 & 1 \\
\hline $\mathrm{PM}_{2.5}$ & Normal Day & Pre Diwali & Diwali & Post Diwali \\
\hline Normal Day & 1 & & & \\
\hline Pre Diwali & 0.76 & 1 & & \\
\hline Diwali & 0.41 & 0.55 & 1 & \\
\hline Post Diwali & 0.14 & 0.51 & 0.41 & 1 \\
\hline
\end{tabular}

Table 4. Summary of air quality during night times of Diwali days.

\begin{tabular}{ccccc}
\hline & \multicolumn{4}{c}{ Correlation Coefficient of Pollutant During Night Time } \\
\hline PM $_{10}$ & Normal Day & Pre Diwali & Diwali & Post Diwali \\
\hline Normal Day & 1 & & & \\
Pre Diwali & 0.49 & 1 & 1 & \\
Diwali & 0.62 & 0.48 & 0.33 & 1 \\
Post Diwali & 0.51 & 0.42 & Diwali & \\
\hline PM & Normal Day & Pre Diwali & & \\
\hline Normal Day & 1 & & 1 & 1 \\
Pre Diwali & 0.49 & 1 & 0.04 & \\
Diwali & 0.01 & 0.57 & & \\
Post Diwali & 0.78 & 0.41 & & \\
\hline
\end{tabular}


Table 5. Summaries of $\mathrm{PM}_{10} \& \mathrm{PM}_{2.5}$ during Diwali days.

\begin{tabular}{cccc}
\hline Parameters & Correlation & Regression & $\mathrm{R}^{2}$ \\
\hline During Diwali Days & 0.824 & $\mathrm{PM}_{10}=0.97$ & 0.68 \\
& & $\mathrm{PM}_{2.5}=0.69$ & 0.94 \\
Day Time (Diwali day) & 0.97 & $\mathrm{PM}_{10}=0.85$ \\
& & $\mathrm{PM}_{2.5}=1.11$ & \\
Day Time (Diwali day) & 0.78 & $\mathrm{PM}_{10}=0.69$ & 0.6 \\
\hline
\end{tabular}

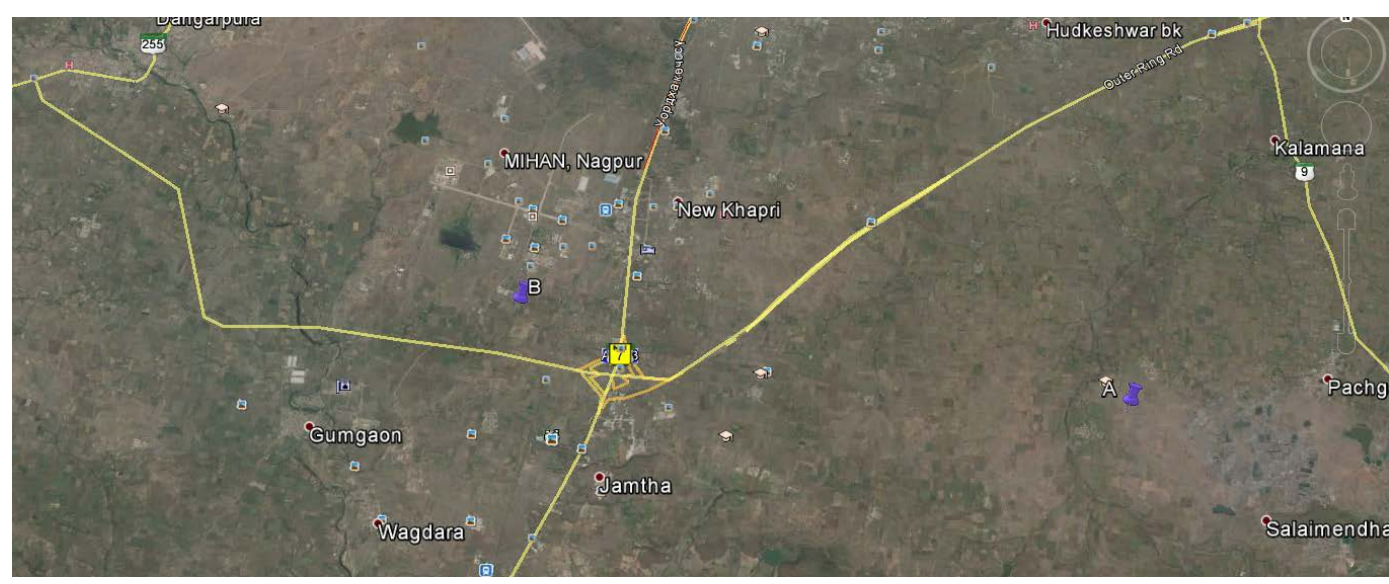

Figure 14. Satellite image of sampling site at Nagpur.

plotted by using surfer. The model has assumed the study area as a centre point and plots contours of dispersion of pollutants.

This shows that approximate $10 \mathrm{~km}$ Area of Nagpur from sampling site. This covers the Mihan, Newkhapri, Gumgaua, Jamthaand and Wagdara etc. (Figure 14). The people of these localities are more affected by these pollutants.

\section{Conclusion}

Study of pre Diwali, Diwali, post Diwali has been investigated in residential Area Nagpur. This study has shown the pollution levels in terms of particulate matter which is higher than the normal day and it remains in the atmosphere after the two days of festival. The particulate matter $\left(\mathrm{PM}_{10} \& \mathrm{PM}_{2.5}\right)$ exceeds the CPCB standard. Though this is time of merriment and income generation, this leads to risk of endangering of health of people.

\section{Acknowledgements}

This study was carried out as part of the project funded by Council of Scientific Industrial Research. The authors are grateful to Director NEERI, Nagpur for according to permission to publish this paper.

\section{Recommendations}

It is advice to the community of society that they should not only look for income generation and amusement during festival but should also consider the damaging effect in the environment in terms of air quality. We should look for an alternative way from which one can enjoy the festival more but not creating any damage to environment. It has been suggested to the people do not use more cracker during Diwali as creating noise and air pollution both. As it is a lighting festival so we should use some lamps and candle for more enlightenment.

\section{References}

[1] Robichaud, A. and Menard, R. (2014) Multi-Year Objective Analysis of Warm Season Ground-Level Ozone and PM 2.5 
over North America Using Real Time Observation and Canadian Operational Air Quality Model, Atoms. Chemical Physics, 14, 1769-1800. http://dx.doi.org/10.5194/acp-14-1769-2014

[2] Central Pollution Control Board (CPCB) (2005) Guidelines for National Ambient Air Quality Monitoring, Series: NAAQM/25/2003-04. Parivesh Bhavan, Delhi.

[3] Nigam, S., Rao, B.P.S., Kumar, N. and Mhaisalkar, V.A. (2015) Air Quality Index-A Comparative Study for Assessing the Status of Air Quality. Research Journal of Engineering and Technology, 6(2).

[4] Ravindra, K., Mor, S. and Kaushik, C.P. (2003) Short Term Variation in Air Quality Associated with Fireworks Events: A Case Study. Journal of Environmental Monitoring, 5, 260-264. http://dx.doi.org/10.1039/b211943a

[5] Singh, D.P., Gadi, R., Mandal, T.K., Dixit, C.K., Singh, K., Saud, T., et al. (2009) Study of Temporal Variation in Ambient Air Quality during Diwali Festival in INDIA. Journal of Environmental Monitoring \& Assessment, 169, 1-13. http://dx.doi.org/10.1007/s10661-009-1145-9

[6] Mandal, P., Prakash, M. and Bassin J.K. (2012) Impact of Diwali Celebrations on Urban Air and Noise Quality in Delhi City, India. Environment Monitoring Assessment, 184, 209-215. http://dx.doi.org/10.1007/s10661-011-1960-7

[7] Chauhan, V.S., Singh, B., Ganesh, S. and Zaidi, J. (2014) Status of Air Pollution during Festival of Lights (Diwali) in Jhansi, Budelkhand Region, India. Asian Journal of Science and Technology, 5, 187-191.

[8] Srivastava, R.K., Sagar, K. and Beig, G. (2014) Measurement of Particulate Pollution in Jabalpur City during Diwali Festival. International Journal of Environmental Science \& Toxicology, 2, 136-142.

[9] Thakur, B., Chakraborty, S., Chakrabarty, A.D.S. and Srivastava, R.C. (2010) Air Pollution from Fireworks during Festival of Lights (Deepawali) in Howrah, India-A Case Study.

[10] RIDEM (2003) Rhode Island Department of Environmental Management-Division of Air Resources. Air Pollution Control Regulation No.10. http://www.epa.gov/region1/topics/air/sips/ri/2003_RI_reg_10.pdf

[11] Anderson, H.R., Atkinson, R.W., Peacock, J.L., Sweeting, M.J. and Marston, L. (2005) Ambient Particulate Matter and Health Effect; Publication Bias in Studies of Short-Term Association. Epidemiology, 16, 155-163. http://dx.doi.org/10.1097/01.ede.0000152528.22746.0f

[12] Analitis, A., Katsouyanni, K., Dimakopoulou, E., Samoli, A.K., Nikolouopoulos, Y., Petasakis, G., Touloumi, J., Schwartz, H., Anderson, H.R., Cambra, K., Forastiere, F., Zmirou, D., Vonk, J.M., Clancy, L., Kriz, B., Bobvos, J. and Pekkanen, J. (2006) Short-Term Effects of Ambient Paricles on Cardiovascular and Resipiratory Mortilaity. Epidemiology, 17, 230-233. http://dx.doi.org/10.1097/01.ede.0000199439.57655.6b

[13] Pope, C.A. and Dockery, D.W. (2006) Health Effects of Fine Particulate Air Pollution; Lines That Connect. Journal of Air and Waste Management Association, 56, 709-742. http://dx.doi.org/10.1080/10473289.2006.10464485

[14] Rao, S.P., Gajghate, D.G., Gavane, A.G., Suryawanshi, P., Chauhan, C., Mishra, S., Gupta, N., Rao, C.V.C., Wate, S.R. (2012) Air Quality Status during Diwali Festival of India: A Case Study. Bulltiiein of Envirionmental Toxicology.

[15] Bull, M.J., Agran, Gardner, H.G., Laraque, D., Pollack, S.H., Smith, G.A., et al. (2001) Committee on Injury and Poison Prevention. Fireworks-Related Injuries to Children. American Academics of Pediatrics, 108, 190-201.

[16] Tian, Y.Z., Wang, J., Peng, X., Shi, G.L. and Feng, Y.C. (2014) Estimation of the Direct and Indirect Impacts of Fireworks on the Physicochemical Characterstics of Atmospheric $\mathrm{PM}_{10} \& \mathrm{PM}_{2.5}$. Atmospheric Chemistry and Physics, 14, 9469-9479. http://dx.doi.org/10.5194/acp-14-9469-2014

[17] Ekpenyong, E.C., Eltebong, E.O., Akpan, E.E., Samson, T.K. and Danierl, E.N. (2012) Urban City Transportation Mode and Respiratory Health Effect of an Air Pollution: A Cross Sectional Study among Transit and Non Transit Worker in Nigeria. BMJ Open, 2, e001253. http://dx.doi.org/10.1136/bmjopen-2012-001253

[18] World Health Organization (WHO) (2005) Occupational and Community Noise. WHO-OMS. http://www.who.int.Inffs/en/fact.html 